\title{
MODAL SOSIAL UNTUK PENGEMBANGAN ORGANISASI: STUDI PADA AISYIYAH KOTA BAUBAU
}

\author{
Andy Arya Maulana Wijaya ${ }^{1}$, Safrin Salam² \\ 1 Prodi Ilmu Pemerintahan, Fakultas Ilmu Sosial dan Ilmu Politik, Universitas Muhammadiyah Buton, \\ 2 Prodi Ilmu Hukum, Fakultas Hukum Universitas Muhammadiyah Buton, \\ Jl. Betoambari No. 36 Kota Baubau \\ Email; bulawambona.87@gmail.com, salamsafrin2@gmail.com
}

\begin{abstract}
Abstrak
Penelitian ini bertujuan untuk mengkaji kapabilitas modal sosial Aisyiyah kota baubau, mengingat kepercayaan (trust) masyarakat kepada gerakan organisasi ini secara umum cenderung meningkat dengan sejumlah perkembangan amal usaha Muhammadiyah Kota Baubau. Penelitian ini mengkategorikan bahwa modal sosial intern lebih kuat ketimbang modal sosial ekstern organisasi, hal ini memberikan deskripsi bahwa Aisyiyah Kota Baubau mampu mengelola kader dan amal usaha sebagai bentuk upaya pengembangan organisasi, hanya saja masih belum optimal dalam membangung network terhadap stakeholder dan pemerintah daerah. Disisi lain, Aisyiyah Kota Baubau dalam perkembangannya turut dipengaruhi dengan kondisi sosial budaya masyarakat buton yang sedikit banyak memiliki jarak secara ideologis dengan muhammadiyah.
\end{abstract}

Kata kunci: Modal Sosial, Organisasi dan Aisyiyah

\begin{abstract}
Gender segregation within the organization is still common, including for Muhammadiyah as a group of men and Aisyiyah as a group of women. This study aims to examine Social Capital Capability of Aisyiyah Baubau, according to the trust of the society to the movement of this organization generally increase with a number of Amal Usaha Muhammadiyah (AUM) in Baubau City. This study categorizes that internal social capital is stronger than the external social capital of the organization's, it provides a description that Aisyiyah Baubau City is capable of managing members and AUM as a form of organizational development effort, it's just not optimal in building network against stakeholders and local government. In the other hand, aisyiyah baubau in also influenced by social cultural condition of buton society which has a lot of distance ideologically with muhammadiyah.
\end{abstract}

Keywords: Social Capital, Organization dan Aisyiyah 


\section{SANG PENCERAH}

Volume 5, Nomor 1, Februari 2019, Hlm. 7-18

Andy Arya Maulana Wijaya, Safrin Salam: Modal Sosial untuk ...

\section{Pendahuluan}

Menjadi bagian dari
Muhammadiyah, Aisyiyah terbukti
juga mampu memberi peran-peran
publik, utamanya bagi sektor yang
dibidanginya yakni kaum perempuan.
Berperan sebagai sister organization
dari Muhammadiyah adalah point
penting untuk melihat kontribusi
Aisyiyah sebagai organisasi
perempuan yang kini hampir
berusia satu abad (Burhani, 2016).
Dimanapun itu, Aisyiyah hadir
sebagai penyeimbang wacara
gerakan Muhammadiyah baik dari
segi organisasi maupun amal
usahanya.

Kontribusi tersebut meliputi antara lain 13 ribu amal usaha pendidikan anak usia dini, amal usaha pendidikan dasar dan menengah; 13 pendidikan tinggi; 568 koperasi; 1.029 Bina Usaha Ekonomi Keluarga (1029); dan amal usaha di bidang kesehatan yang dikelola Muhammadiyah-Aisyiyah berupa 87 Rumah Sakit Umum, 16 Rumah Sakit Ibu dan Anak, 70 Rumah Sakit Bersalin, 106 Balai Pengobatan, 20 Balai Kesehatan Masyarakat (Balkesmas), 76 BKIA, 105 Rumah Bersalin, serta Posyandu yang tersebar di seluruh Indonesia (http://www.mampu.or.id/id/part ner/aisyiyah, diakses 28 Juli 2017).

Dengan kapasitas organisasi seperti demikian, menjadikan Aisyiyah cukup popular di masyarakat Indonesia sekalipun Muhammadiyah lebih memiliki kekuatan popularitas yang lebih. Begitupun dengan kontribusi
Aisyiyah Kota Baubau dalam beberapa tahun ini yang seringkali hadir di panggung publik Kota Baubau, baik sebagai organisasi bagi kaum perempuan muhammadiyah Aisyiyah juga hadir membersamai beberapa program pemerintah seperti Community Tuberculosis (TB), HIV / AIDS di Kota Baubau.

Penelitian ini kemudian didasarkan pada tiga pemahaman tentang kinerja publik Aisyiyah bahwa, pertama; Jaringan (network) yang telah dibangun oleh Aisyiyah sebagai bagian dari Muhammadiyah, memiliki pegakuan oleh publik luas sehingga posisi ini memungkinkan Aisyiyah Kota Baubau mampu mengembangan organisasi melalui Amal Usaha lainnya. Kedua; Kepercayaan (trust) publik Kota Baubau dengan Muhammadiyah melalui sejumlah Amal Usahanya, turut memberikan efek positif bagi pandangan publik kepada Muhammadiyah dan juga Aisyiyah. Ketiga; Beberapa program Muhammadiyah dan Aisyiyah Kota Baubau bidang sosial kemasyarakatan mendapat respon positif dari Pemerintah Daerah Kota Baubau.

Peran-peran publik seperti tersebut di atas, memungkinkan untuk Aisyiyah memperoleh kepercayaan (trust) dari masyarakat. Disamping itu, di tingkatan daerah peran Aisyiyah juga menjadi subordinasi bagi peran muhammadiyah secara umum. Seperti halnya yang terjadi di Kota 


\section{SANG PENCERAH}

Volume 5, Nomor 1, Februari 2019, Hlm. 7-18

Andy Arya Maulana Wijaya, Safrin Salam: Modal Sosial untuk ...

Baubau, peran amal usaha Muhammadiyah dalam hal ini Perguruan Tinggi Muhammadiyah yakni Universitas Muhammadiyah Buton serta sekolah dasar hingga menengah, memberi andil yang cukup signifikan bagi perkembangan Pendidikan di Kota Baubau. Untuk, PTM Universitas Muhammadiyah Buton misalnya, dimana kini menjadi salah satu universitas terbesar dengan jumlah mahasiswa yang juga besar. Bagi publik Kota Baubau, Muhammadiyah lebih dikenal pada perannya dalam Pendidikan ketimbang lembaga dakwah amar maruf nahi mungkar.

Kondisi ini juga menjadi penting sebagai bangunan modal sosial Muhammadiyah bagi publik Kota Baubau secara umum. Begitupun juga terhadap Pimpinan Daerah Aisyiyah yang tentu lekat oleh keberadaan PD Muhammadiyah dan Amal Usahanya. Hingga kini, PD Aisyiyah dapat dilihat kontribusinya bagi publik seperti misalnya Raudhatul Antfal dan Taman Kanak-Kanak (TK) Aisyiyah, Nasiyatul Aisyiyah dengan sejumlah program progendernya, lalu ada Community TB Care Aisyiyah. Program ini merupakan upaya penanggulangan TB berbasis masyarakat yang merupakan bagian dari program Majelis Kesehatan Aisyiyah di bawah pembinaan pimpinan Pusat Aisyiyah.

Peran publik Aisyiyah seperti halnya yang tergambarkan diatas menjadi sumber-sumber daya, aktual atau virtual (tersirat) yang berkembang pada seorang individu atau sekelompok individu karena kemampuan untuk memiliki suatu jaringan yang dapat bertahan lama dalam hubungan-hubungan yang lebih kurang telah diinstitusikan berdasarkan pengetahuan dan pengenalan timbal balik. Disisi lain, kapasitas modal sosial terbangun dalam sebuah interaksi yang terus menerus (Bourdiau, P. And Wacquant, L: 1992). Dengan kondisi bahwa peran-peran publik yang dilakukan Pimpinan Daerah Aisyiyah Kota Baubau, melalui program-program yang berinteraksi langsung dengan masyarakat seperti halnya pendidikan dan kesehatan. Mengingat bahwa, Aisyiyah Kota Baubau lebih banyak hadir dalam bentuk amal usaha yang yakni pada bidang Pendidikan, kesehatan, dan sosial. maka, pimpinan daerah Asiyiyah Kota Baubau dipandang untuk dapat berkembang dalam hal program dan pengembangan amal usaha lainnya. Jaringan interaksi dan pengenalan Aisyiyah oleh publik sebagai penyedia layanan publik, menjadi unsur utama modal sosial Aisyiyah yakni kepercayaan (trust).

Konsep modal sosial telah dijadikan pertimbangan penelitian pada berbagai bidang (multidisipliner) dalam beberapa dekade terakhir ini. Dalam kajiannya juga, modal sosial tidak berlaku secara individual ataupun pada satu kelompok saja, namun bertalian dengan interaksi yang juga dibangun oleh individu 


\section{SANG PENCERAH}

Volume 5, Nomor 1, Februari 2019, Hlm. 7-18

Andy Arya Maulana Wijaya, Safrin Salam: Modal Sosial untuk ...

maupun kelompok dengan kelompok lain (linking) (Liu,dkk; 2014).

Memahami modal sosial dapat dilihat dari 3 komponen modal sosial, yakni Bonding modal sosial adalah keseimbangan antara modal sosial yang mengatur keharmonisan dan solidaritas hubungan internal antara sesama anggota kelompok. Sementara itu, bridging adalah kerjasama yang saling menguntungkan dan berhubungan dengan anggota kelompok lainnya. Linking adalah hubungan antara komunitas dan komunitas lain dan pemerintah (Wijaya, 2016).

Dalam pandangan lainnya, menganggap bahwa modal sosial sangat penting bagi komunitas karena (1) memberikan kemudahan dalam mengakses informasi bagi anggota komunitas; (2) menjadi media pembagian kekuasaan dalam komunitas; (3) mengembangkan solidaritas; (4) memungkinkan mobilisasi sumber daya komunitas; (5) memungkinkan pencapaian bersama; dan (6) membentuk perilaku kebersamaam dan berorganisasi komunitas (Portes; 1998). Berdasarkan deskripsi di atas, fokus penelitian ini adalah bagaimanakah modal sosial untuk pengembangan organisasi studi pada Aisyiyah Kota Baubau.

Tujuan penelitian ini untuk mengetahui modal sosial untuk pengembangan organisasi studi pada Aisyiyah Kota Baubau.

\section{Metode Penelitian}

Penelitian ini didesain dengan menggunakan penelitian Kualitatif, melalui pendekatan studi kasus intrinsik dengan mempelajari kasus agar dapat merangkum kompleksitas makna ke dalam sebuah laporan yang padat namun dalam bentuk uraian kasus yang lebih bersifat deskriptifnaratif (Denzin \& Lincoln; 2014). Sampel diambil menggunakan non probability sampel dengan pendekatan purposive sampel. Data diperoleh melalui wawancara mendalam dengan sejumlah tokoh Aisyiyah serta kelompok masyarakat yang berinteraksi langsung dengan PD Aisyiyah Kota Baubau, dan juga melakukan observasi kegiatannya didukung pula oleh telaah dokumen yang relevan. Analisis data menggunakan model interaktif, dan disajikan secara deskriptif.

\section{Pembahasan}

\section{Dinamika PD Asyiyah di Kota Baubau}

Salah satu metode untuk melakukan identifikasi terhadap dinamika sebuah organisasi dan untuk mengetahui potensi modal sosial (social capital) nya, dapat diawali dengan menemukenali dan mengkaji dinamika organisasi dan kontribusinya bagi lingkungan sosial. Hal ini dapat dikaji melalui karakteristik ideologis, karakteristik sosial budaya dan karakteristik lingkungan yang juga turut memengaruhi opini kader dan 


\section{SANG PENCERAH}

Volume 5, Nomor 1, Februari 2019, Hlm. 7-18

Andy Arya Maulana Wijaya, Safrin Salam: Modal Sosial untuk ...

masyarakat terhadap keberadaan Aisyiyah.

Sebagai bagian dari Muhammadiyah yang khusus membidangi kaum perempuan sebagai patron gerakannya, Aisyiyah sejatinya memiliki kontribusi yang berbeda dengan apa yang dilakukan oleh muhammadiyah (Salman: 2011). Hanya saja, sekalipun secara organisasional Aisyiyah dan Muhammadiyah adalah dua entitas organisasi yang berbeda, namun persepsi publik dua organisasi ini adalah cenderung sama.

Aisyiyah di Kota Baubau pertama memulai kepengurusan organisasinya pada tahun 2001 kemudian seiring perkembangan gerakan muhammadiyah di Kota Baubau ikut mendorong eksistensi Aisyiyah, sebagai gerakan yang berbasis perempuan di tubuh muhammadiyah. Setidaknya hingga kini, Aisyiyah dapat ditemukenali sebagai organisasi yang menjadi bagian dari Muhammadiyah, yang bergerak pada beberapa bidang diantaranya sosial kemasyarakatan, kaderisasi dan pendidikan.

Hingga tahun 2018, Amal Usaha Muhammadiyah yang khusus dikelola oleh Pimpinan Daerah Aisyiyah Kota Baubau, diantaranya adalah Bustanul Antfal yang terletak di jalan jenderal sudirman Kota Baubau, dan Raudhatul Antfal terletak di jalan pahlana Kota Baubau. Dengan adanya dua institusi pendidikan tersebut, maka ikut memperkenalkan nama dan kiprah Aisyiyah pada masyarakat Kota
Baubau. Disisi lain, Amal Usaha juga menjadi wadah bagi kader untuk mengabdikan diri sebagai guru, sehingga pemberdayaan kader melalui keberadaan amal usaha saling mendukung bagi perkembangan Aisyiyah.

Dalam beberapa wawancara dengan masyarakat, mengungkap bahwa Aisyiyah lebih dikenali sebagai bagian dari Muhammadiyah atau Universitas Muhammadiyah Buton ketimbang, Aisyiyah dalam statusnya sebagai organisasi otonom yang memiliki bidang pergerakan sendiri. Dengan begitu keberadaan Aisyiyah tidak terlepas juga dengan pergerakan Muhammadiyah dan Universitas Muhammadiyah Buton. Dalam kaca mata publik, Aisyiyah belum mampu melepaskan diri dari perkembangan Muhammadiyah, sekalipun secara organisasi sejatinya berdiri sendirisendiri. Maka bagi publik di Kota Baubau, Muhammadiyah dan Aisyiyah adalah organisasi yang dikenal melalui institusi pendidikan yang dikelolanya. Di bidang sosial kemasyarakatan, Aisyiyah Kota Baubau turut serta dalam mensosialisasikan penanggulangan penyakit tuberkolosis kepada masyarakat kurang mampu. Kegiatan tersebut merupakan bagian dari program Majelis Kesehatan Aisyiyah dibawah pembinaan Community TB Care Aisyiyah SSR Kota Baubau yang diselenggarakan hingga tahun 2020 nanti.

Program ini dilaksanakan dengan bekerjasama antara Aisyiyah Kota Baubau dan Dinas Kesehatan 


\section{SANG PENCERAH}

Volume 5, Nomor 1, Februari 2019, Hlm. 7-18

Andy Arya Maulana Wijaya, Safrin Salam: Modal Sosial untuk ...

Kota Baubau. Program ini cukup memberikan nilai bagi gerakan Aisyiyah di masyarakat serta memungkinkan adanya sosialisasi perihal peran publik Aisyiyah. Untuk mendukung hal tersebut Aisyiyah Kota Baubau juga bertekad untuk mampu menjalankan Program umum, meliputi program konsolidasi ideologi, konsolidasi gerakan, konsolidasi kepemimpinan, manajemen gerakan, penguatan cabang dan ranting, serta penguatan amal usaha, sesuai dengan program kerja Aisyiyah Kota Baubau periode 2015-2020.

Dalam sisi kapabilitas organisasi, Aisyiyah juga ikut berkembang dengan jumlah anggota dan simpatisan yang terus meningkat. Dalam observasi kuantitas kader menjelaskan bahwa keanggotaan Aisyiyah terbuka untuk siapa saja. Sehingga secara kuatitatif organisasi ini memiliki kader yang dari berbagai latarbelakang. Jumlah kader terbesar adalah masyarakat yang memiliki hubungan secara ideologis maupun pragmatis dengan muhammadiyah. Hal ini juga diperkuat dengan pengembangan Pimpinan Cabang Aisyiyah Kota Baubau yang hampir mencapai 8 kecamatan se-Kota Baubau.

Tercatat bahwa keanggotaan Aisyiyah Kota Baubau didominasi oleh akademisi dan Pegawai Negeri Sipil Daerah. Pemahaman mengenai gerakan Muhammadiyah dan Aisyiyah diperkuat melalui pelaksanaan Baitul Arqam tingkat Kota Baubau yang terselenggara terakhir kali pada desember 2017. Selain itu, status keanggotaan dicerminkan dengan kepemilikan kartu Anggota Aisyiyah Kota Baubau juga tetap memiliki Kartu Anggota Muhammadiyah.

Betapapun demikian, sejatinya Aisyiyah maupun Muhammadiyah hadir bukan saja sebagai organisasi masyarakat, akan tetapi sebagai organisasi dakwah. Oleh karena ini juga, patut diakui bahwa ideologi muhammadiyah belum begitu tersosialisasikan dengan baik kepada masyarakat Kota Baubau. Masih terdapat beberapa pandangan bahwa Muhammadiyah adalah sebuah aliran agama atau mazhab tertentu. Pada sejumlah observasi dan pengamatan, secara ideologis masih terdapat jarak perbedaan antara nilai-nilai kemuhammadiyahan dan budaya masyarakat setempat. Hal ini dapat diamati pada ritual masyarakat yang membudaya seperti tahlilan, takziah dan ziarah kubur. Secara khusus Aisyiyah digambarkan sebagai organisasi masyarakat yang menjadi bagian dari Muhammadiyah, ketimbang gerakan ideologis berbasis dakwah amal ma'ruf nahi mungkar seperti yang menjadi visi gerakan Aisyiyah.

Disisi lain, kesadaran anggota Aisyiyah Kota Baubau sebagai individu bagian dari kelompok dan organisasi, serta hubungan antara masyarakat akan membentuk tipologi modal sosial yang kuat sebagai upaya pengembangan organisasi pimpinan daerah Aisyiyah Kota Baubau. Betapapun demikian, keanggotaan 


\section{SANG PENCERAH}

Volume 5, Nomor 1, Februari 2019, Hlm. 7-18

Andy Arya Maulana Wijaya, Safrin Salam: Modal Sosial untuk ...

Aisyiyah Kota Baubau yang cenderung egaliter, yakni jalur kaderisasi organisasi belum begitu menjadi perhatian penting sebagai prasyarat keanggotaan, hanya saja kajian mengenai perkembangan Aisyiyah secara organisasional lebih berkembang ketimbang perkembangan ideologis.

Narasi lebih luas dalam kajian modal sosial, faktor homogenitas dan heterogenitas memegang peranan penting sebagai bagian dari kinerja organisasi begitupun dengan yang berlangsung sebagai dinamika organisasi Aisyiyah Kota Baubau. Seperti halnya tentang modal sosial dikalangan wirausahawan perempuan dan laki-laki menemukan bahwa secara umum perempuan memiliki jaringan yang lebih homogen dibandingkan dengan laki-laki, dan terutama lebih cenderung mengandalkan kerabat sebagai anggota jaringan (Field; 2010).

\section{Kapabilitas Modal Sosial Aisyiyah Kota Baubau}

Mencermati kondisi diatas, bahwa dinamika yang ditunjukkan oleh Aisyiyah Kota Baubau, dapat dipetakan menjadi tipologi berlangsungnya fungsi modal sosial (social capital) melalui sejumlah interaksi organisasi yang terselenggara. Sebagai mana konsep dan interaksi jaringan yang berlangsung didalamnya, studi kapabilitas modal sosial Aisyiyah Kota Baubau dapat dideskripsikan sebagai berikut:

\section{Bonding Social Capital: Saling Percaya (Trust) dan Hubungan antar anggota.}

Perkembangan mendasar dari Áisyiyah hingga kini adalah interaksi yang bersifat internal dalam organisasi Aisyiyah Kota Baubau (bonding social capital), hubungan ini dapat terlihat dari aktivitas-aktivitas organisasi yang secara rutin dijalankan oleh Aisyiyah sebagai bentuk konsolidasi program kerja dan gerakan organisasi.

Intensitas yang sering, turut membangun bonding yang baik pada kader Aisyiyah dimana pekerjaan sebagian besar pengurus dan kader adalah akademisi/Tenaga pengajar di sejumlah amal usaha muhammadiyah dan Aisyiyah yang ada di Kota Baubau. Dengan begitu, saling kerjasama lebih mudah dengan mudahnya akses untuk saling bertemu dan berdiskusi. Disisi lain, dukungan juga diberikan kepada pimpinan amal usaha pada setiap individu yang bekerja untuk turut serta dalam organisasi Aisyiyah Kota Baubau.

Bentuk interaksi lainnya adalah adanya norma yang kemudian dibangun bersama antara setiap kader. Hal ini teramati dalam terbentuknya pimpinan cabang Aisyiyah pada 8 kecamatan di Kota Baubau. Untuk memperkuat interaksi ini, Aisyiyah Kota Baubau juga melaksanakan 


\section{SANG PENCERAH}

Volume 5, Nomor 1, Februari 2019, Hlm. 7-18

Andy Arya Maulana Wijaya, Safrin Salam: Modal Sosial untuk ...

kajian yang dirangkaikan dengan arisan yang secara rutin dilakukan setiap awal bulan, menjadikan wadah silaturahim pengurus dan sekaligus kader Aisyiyah Kota Baubau. Aktivitas ini juga didukung dengan keberadaan Gedung yang secara khusus diperuntukan sebagai kantor pimpinan daerah Aisyiyah Kota Baubau, terletak di Kompleks Ruko Kav.2 Jalan Betoambari Kota Baubau. Keberadaan gedung perkantoran yang diresmikan pada April 2018 tersebut bagi Aisyiyah, juga mendukung bagi lokasi kegiatan maupun akses masyarakat untuk mengetahui lebih banyak tentang Aisyiyah Kota Baubau.

\section{Bridging Social Capital: Interaksi Internal Organisasi}

Untuk mengamati terwujudnya bridging social capital dalam organisasi dapat diamati pada interaksi yang kuat antara bonding social capital, yaitu nilainilai yang diyakini sebagai norma dan budaya organisasi yang tumbuh serta menjadi tata aturan organisasi yang dipatuhi bersama. Dalam perkembangan struktur organisasi Aisyiyah tingkat kecamatan di seluruh wilayah Kota Baubau. Turut membantu sosialisasi Aisyiyah kepada masyarakat Kota Baubau yang selama ini hanya memahami perihal muhammadiyah saja. Pengurus cabang Aisyiyah menjadi penanda bahwa organisasi ini memiliki kesadaran yang terus tumbuh dan semakin besar.

Dukungan bridging social capital juga teramati dari adanya sekolah tingkat Taman KanakKanak yang dikelola oleh Pimpinan Daerah Aisyiyah Kota Baubau. Tercatat bahwa, Aisyiyah Kota Baubau memiliki dua sekolah tingkat taman kanak-kanak yakni Bustanul Antfal dan Raudhatul Antfal, yang masing-masing memiliki pengelola, guru dan murid. Kepercayaan publik terhadap sekolah ini juga menunjukkan bahwa, kepercayaan publik terhadap Aisyiyah melalui amal usahanya terus bertumbuh. Selain itu juga, adanya sekolah memberikan kesempatan bagi kader dan warga muhammadiyah untuk dapat bekerja sebagai guru maupun tenaga kependidikan. Untuk hal ini, memang menjadi prioritas Aisyiyah Kota Baubau untuk dapat memanfaatkan potensi kader di setiap amal usaha Muhammadiyah dan Aisyiyah Kota Baubau.

Dengan adanya keterlibatan secara aktif pada program penanggulangan Tuberkolosis di Provinsi Sulawesi Tenggara sejak November 2015. Kegiatan yang bertujuan bagi pencegahan penyebaran virus tuberkolosis, HIV/AIDS di Kota Baubau. Dalam pelaksanaanya, program ini melibatkan kader dan warga muhammadiyah di tingkatan kecamatan seluruh Kota Baubau. 


\section{SANG PENCERAH}

Volume 5, Nomor 1, Februari 2019, Hlm. 7-18

Andy Arya Maulana Wijaya, Safrin Salam: Modal Sosial untuk ...

\section{Linking Social Capital: Kerjasama Organisasi Dengan Pemerintah Daerah.}

Mencermati linking social capital dalam organisasi khususnya Aisyiyah Kota Baubau telah terbentuk, hanya saja belum secara optimal memberikan penguatan sebagai elemen modal sosial bagi organisasi. Dalam beberapa program yang berkaitan dengan stakeholder dan pemerintah daerah bagi Aisyiyah, belum begitu berkembang dengan baik. Pada beberapa program yang melibatkan organisasi maupun institusi daerah, dilakukan hanya secara tentative.

Sejak tahun 2015, Aisyiyah Kota Baubau menangani program Community Tubercolosis (TB), HIV/AIDS di Kota Baubau. Dari program ini menjadi indicator untuk mengamati bentuk linking social capital. Melalui program ini, terjalin interaksi antara Aisyiyah Kota Baubau dengan berbagai stakeholder dan pemerintah daerah. Hingga kini, respon warga muhammadiyah dan masyarakat umum tentang kinerja program ini cukup baik, capaian program ini juga mendorong tercapainya penanggulangan TBC di Indonesia, khususnya Kota Baubau.

Mencermati hal ini, kesadaran masyarakat sebagai individu dan kader sebagai bagian organisasi, serta hubungan antara kader dan masyarakat hingga tingkatan kecamatan, dan tentunya pemerintah daerah Kota Baubau. Dengan begitu, kapasitas ini nantinya memungkinkan sebagai kondisi hadirnya kepercayaan masyarakat, stakeholder dan pemerintah daerah kepada peran dan kontribusi Aisyiyah Kota Baubau. Berdasarkan kondisi di atas, maka dapat diamati bahwa tipologi modal sosial yang dimiliki oleh Aisyiyah Kota Baubau adalah sebagai berikut:

\section{Tabel 1 Tipologi Modal Sosial Aisyiyah Kota Baubau}

\begin{tabular}{|c|c|}
\hline $\begin{array}{c}\text { Tipologi } \\
\text { Modal Sosial }\end{array}$ & Keterangan \\
\hline $\begin{array}{l}\text { Bonding Social } \\
\text { Capital }\end{array}$ & $\begin{array}{l}\text { Adanya musyawarah dalam } \\
\text { pengambilan keputusan dan } \\
\text { kepemimpinan kolektif yang efektif, } \\
\text { menjamin terbangunnya } \\
\text { kepercayaan (trust) bagi pengurus } \\
\text { dan kader Aisyiyah. Hal ini } \\
\text { ditunjukkan dengan kesadaran } \\
\text { untuk pengembangan Aisyiyah ke } \\
\text { tingkatan kecamatan dalam } \\
\text { keterlibatan dalam kepengurusan } \\
\text { Pimpinan Cabang. Selain itu, } \\
\text { adanya pertemuan rutin, kajian dan } \\
\text { Arisan. }\end{array}$ \\
\hline $\begin{array}{l}\text { Bridging Social } \\
\text { Capital }\end{array}$ & $\begin{array}{l}\begin{array}{l}\text { Terdapat kepedulian bersama } \\
\text { kaderyang mendorog sikap } \\
\text { produktivitas } \\
\text { mengembangkan organisasi, hal ini }\end{array} \\
\text { ditunjukkan dengan pembentukan } \\
\text { cabang Aisyiyah kepada setiap } \\
\text { kecamatan seluruh wilayah Kota } \\
\text { Baubau. Hal ini juga didukung } \\
\text { dengan keterlibatan kader dalam } \\
\text { amal usaha maupun program } \\
\text { Aisyiyah Kota Baubau. }\end{array}$ \\
\hline $\begin{array}{l}\text { Linking Social } \\
\text { Capital }\end{array}$ & $\begin{array}{l}\text { Kondisi ini ditandai dengan adanya } \\
\text { network, sekalipun untuk bidang } \\
\text { ini belum begitu optimal. Namun } \\
\text { setidaknya, Aisyiyah Kota Baubau } \\
\text { menjadi salah satu penyelenggara } \\
\text { program Community Tubercolosis } \\
\text { (TB), HIV/ AIDS di Kota Baubau, } \\
\text { sedangkan kerjasama dengan } \\
\text { stakeholder dan pemerintah daerah } \\
\text { masih belum optimal. }\end{array}$ \\
\hline
\end{tabular}

Sumber: Data Primer, 2018 


\section{SANG PENCERAH}

Volume 5, Nomor 1, Februari 2019, Hlm. 7-18

\section{Andy Arya Maulana Wijaya, Safrin Salam: Modal Sosial untuk ...}

Perkembangan organisasi dan kaitannya dengan pemanfaatan modal sosial diperlukan kajian terhadap hubunganhubungan antar individu dan budaya organisasi. Melalui kapasitas Modal sosial, dapat diartikan sebagai sumber (resources) yang timbul dari adanya interaksi antar orang-orang dalam suatu komunitas atau organisasi (Suharto; 2011).

\section{Memanfaatkan Modal Sosial Untuk Pengembangan Organisasi}

Organisasi dengan tingkat kolektivitasnya yang tinggi, biasanya kaya akan fungsi modal sosial. Unsur modal sosial yang dominan dalam organisasi yakni jaringan (network) yang terbentuk melalui adanya kepercayaan, pertukaran sosial dan sikap saling terbuka dalam organisasi. Jenis dan karakteristik hubungan antar anggota terjadi berdasar pada kepercayaan dan adanya faktor pertukaran sosial Seseorang yang mempunyai tingkat kepercayaan yang tinggi terhadap anggota lain dan mempunyai pengalaman yang menyenangkan dalam pertukaran sosial cenderung akan bersikap terbuka dan membagi pengetahuan yang dimilikinya (Miliana dan Maldaon; 2015).

Aktivitas organisasi tersebut memungkinkan untuk menjadi elemen penting dalam organisasi. Kondisi ini teramati dalam beberapa kegiatan yang dilakukan diantaranya, pengajian rutin serta aktivitas yang berlangsung di Amal Usaha Muhammadiyah dan aisyiyah yang didalamnya juga terlibat pengurus dan kader Aisyiyah. Disisi lain, intensitas pertemuan adalah implikasi logis dari kondisi tersebut, sehingga mampu memastikan interaksi yang dapat terbangun antar anggota lebih optimal. Terdapat tiga aspek modal sosial internal, yaitu stuructural, relational dan cognitive (Nahapiet dan Ghosal; 1998). Menurutnya seorang anggota bisa saja sangat mempercayai anggota tertentu, sedangkan dengan anggota yang lain tidak.
Maka pertemuan rutin Aisyiyah Kota Baubau menjadi sarana relational yang dapat menjelaskan jenis hubungan yang terjadi antar individu.

Oleh karenanya, Sebagai sebuah hasil interaksi antara orang-orang dalam suatu komunitas, modal sosial yang terbangun tersebut memiliki nilai ekonomis bagi pembangunan masyarakat maupun sebuah organisasi seperti Aisyiyah Baubau. Dalam sebuah kajian umum mengenai peran ini, pemanfaatan modal sosial seperti kepercayaan, jaringan dan kerjasama masyarakat dapat menjadi basis pengembangan sebuah komunitas masyarakat (Bowles and Gintis, 2002; Sudarmo, 2006; Suharto, 2008; Wijaya, 2015). Secara organisasional perkembangan Aisyiyah terus berkembang dan semakin besar, apalagi didukung dengan keberadaaan amal usaha muhammadiyah di Kota Baubau yang terus berkembang dan memperoleh kepercayaan publik Kota Baubau. Namun secara ideologis, Aisyiyah belum optimal hadir sebagai gerakan dakwah amar maruf nahi mungkar bagi masyarakat Kota Baubau. Sehingga jarak organisasi lebih dekat, akan tetapi jarak ideologis masih begitu lebar terhadap publik di Kota Baubau.

Modal sosial yang berlangsung dalam organisasi Aisyiyah Kota Baubau dapat digunakan untuk pengembangan organisasi dengan merujuk pada tipologi modal sosial sebagai konsep dan interaksi jaringan yang berlangsung (Wooclock, 1998; Bodin and Crona, 2009), yaitu bonding social capital yakni mencakup pada pemahaman bersama pada masing-masing anggota, bridging social capital mencakup pada interaksi anggota dalam dan antar organisasi, dan linking social capital mencakup interaksi organisasi dengan stakeholder dan pemerintah daerah. Namun untuk hal ini, Aisyiyah belum optimal mengelola network dengan pemerintah daerah. 


\section{SANG PENCERAH}

Volume 5, Nomor 1, Februari 2019, Hlm. 7-18

\section{Andy Arya Maulana Wijaya, Safrin Salam: Modal Sosial untuk ...}

Dengan kapasitas modal sosial memungkinkan pengembangan Aisyiyah pada beberapa bidang sosial kemasyarakatan lainnya, misalnya advokasi, pembinaan serta pendampingan masalah sosial kemasyarakatan khususnya yang berkaitan dengan kaum perempuan. Hanya saja perhatian khusus pada kebangkrutan nilai-nilai agama dan moral, gaya hidup konsumeristik, lingkungan hidup, gender equality, lingkungan hidup, KDRT, keadilan dan sejenisnya (Burhani, 2016). Betapapun demikian, kapabilitas modal sosial tidak dapat dilepaskan dengan kondisi sosial budaya masyarakat Kota Baubau. Secara organisasi, Aisyiyah dapat diterima sebagai bagian dari Muhammadiyah yang telah berkontribusi bagi pendidikan di Kota Baubau. Hanya saja, kebudayaan masyarakat Baubau yang cenderung berjarak secara ideologis dengan Muhammadiyah. Sehingga Aisyiyah lebih diterima sebagai bagian organisasi Muhammadiyah yang fokus pada pendidikan ketimbang sebagai organisasi dakwah amar maruf nahi mungkar.

\section{Simpulan}

Simpulan penelitian ini bahwa menemukan bahwa Aisyiyah secara organisasional terus berkembang di Kota Baubau. Kapabilitas modal sosial dalam komponen bonding, bridging dan linking modal sosial yang ditunjukkan berlangsung tertutup dalam pengertian bahwa Aisyiyah Kota Baubau mampu mengelola kader dan amal usaha dalam pengembangan organisasi, hanya saja masih cenderung belum optimal dalam membangung network terhadap stakeholder dan pemerintah daerah pada program-program publik yang berkenaan dengan misi gerakan sosial Aisyiyah. Disisi lain, perkembangan Aisyiyah turut dipengaruhi dengan kondisi sosial budaya masyarakat Kota Baubau yang memiliki jarak secara ideologis dengan gerakan dakwah Muhammadiyah. Untuk itu, keberlangsungan modal sosial pada Aisyiyah Kota Baubau diperlukan sebuah kondisi dimana dukungan kepemimpinan transformasional, interaksi yang produktif, jaringan kerjasama dengan berbagai pihak utamanya pemerintah daerah, serta budaya organisasi dan sikap pengurus yang positif untuk terus saling memotivasi dalam memahami arah gerakan organisasi.

\section{Daftar Pustaka}

Bourdiau, P. And Wacquant, L. (1992). An Invitation to Reflexive ociology. Chicango. University of Chicango Press.

Burhani, Ahmad Najib. (2016). Muhammadiyah Berkemajuan: Pergeseran dari Puritanisme ke Kosmopolitanisme, Bandung: PT. Mizan Pustaka.

Denzin, N. K., \& Lincoln, Y. S. (2014). Handbook of qualitative research. Yogyakarta: Pustaka Pelajar.

Cresswell, John. W, (2010), Research Design : Pendekatan Kualitatif, Kuantitatif dan Mixed, Yogyakarta : Pustaka Pelajar.

Eversole, Robyn. (2011)., Community Agency and Community Engagement: Re-theorising Participation in Governance, Journal of Public Policy / Volume 31 pp 51-71, http://journals.cambridge.org/abstract _S0143814X10000206 (10/10/2013. pukul 22.00 wib)

Field, John. (2010)., Modal Sosial, Bandung: Kreasi Wacana.

Liu, J., Qu, H., Huang, D., Chen, G., Yue, X.,Zhao, X., Liang, Z. (2014). The Role of Sosial Capital in encouraging Residents pro-environmental Behaviours in 


\section{SANG PENCERAH}

Volume 5, Nomor 1, Februari 2019, Hlm. 7-18

\section{Andy Arya Maulana Wijaya, Safrin Salam: Modal Sosial untuk ...}

Community Based Ecotourism. Tourism Management 41, 190-201

Miles dan Huberman, (2009). Analisis Penelitian Kualitatif, Jakarta: UI Press

Milana, Elias and Maldaon, Issa. (2015). Social Capital: A Comprehensive Overview at Organizational Context. Periodica Polytechnica Social and Management Sciences. 23(2), pp. 133-141

Nahapiet, J. and Ghoshal, S. (1998). Social Capital, Intellectual Capital and The organizational Advantage. Academy of Management Review, Vol. 23 (2). , pp. 242-66.

Nugroho, Riant. (2014)., Kebijakan Publik di Negara-Negara Berkembang, Yogyakarta: Pustaka Pelajar.

Portes, Alejandro. (1998). Sosial Capital: Its Origins and Application in Modern Sociology. Annual Review Sociology, vol. 24: $1-24$

Putnam, Robert D. 1993. The Prosperous Community: Sosial Capital and Public Life. The American Prospect No. 13 Spring.

Salman, Ismah, (2011). Peran organisasi Aisyiyah dalam mewujudkan keluarga sakinah dikalangan anggota, http://lib.ui.ac.id/opac/themes/libri2/ detail.jsp?id=92687\&lokasi=lokal, diakses 27 Juli 2017.

Suharto, Edi, (2011)., Kebijakan Sosial Sebagai Kebijakan Publik, Bandung: Alfabeta.

Sudarmo, (2011). Isu-Isu Administrasi Publik dalam Perspektif Governance, Surakarta: Smart Media.

Syahra, R. (2003). Modal sosial: Konsep dan aplikasi. Jurnal Masyarakat dan Budaya, $5(1), 1-22$.
Sudarmo. (2008). Social Capital untuk Community Governance, Jurnal Spirit Publik, Volume 4, Nomor 2 Halaman 101112.

Wijaya, Andy Arya Maulana. 2016. Modal Sosial untuk Kapasitas Community Governance (Studi Kasus Perempuan Pesisir Kelurahan Sulaa Kota Baubau). Jurnal Ilmu Pemerintahan : Kajian Ilmu Pemerintahan dan Politik Daerah Vol. 1 No. 1 April 2016 